and similar software but a long sequence of consecutive tests is required. ${ }^{12}$

It might therefore be more effective if a less sensitive test was used in the first place. With the appearance of FASTPAC and other simple test programs it seems that computerised field analysis is approaching the performance of machines such as the venerable Friedmann visual field analyser. Is the emperor's new suit being replaced by something more appropriate for everyday use? Having been to the limits of complex physiological measurement of visual field, it is timely to establish the minimum test strategy to enable us to make practical management decisions. We should develop a pragmatic view of testing the visual field.

Tennent Institute of Ophthalmology,

Western Infirmary,

Glasgow G11 6NT

1 The emperor's new clothes. Hans Andersen's Fairy Tales. London: Hodder and Stoughton, 1923: 403-66.

2 Cyrlin MM. Automated perimetry. In: Ritch R, Shields MB, Krupin T, eds. The glaucomas. St Louis: Mosby, 1989: 403-66
3 Chauhan BC, Drance SM, Douglas GR. The use of visual field indices in detecting changes in the visual field in glaucoma. Invest Ophthalmol Vis $\mathrm{Sc}$ 1990; 31: 512-20.

4 Hitchings RA, Migdal CS, Wormald R, Poinooswamy D, Fitzke F. The primary treatment trial: changes in the visual field analysis by computerassisted perimetry. Eye $1994 ; 8$ : 117-20.

5 Littmann H. Zur Bestimmung der Wahren Grösse eines Objektes auf dem Hintergrund des lebender Auges. Klin Monatsbl Augenheilkd 1982; 180: 286-9.

6 Balazsi AG, Drance SM, Schulzer M. Neuroretinal rim area in suspected glaucoma and early chronic open angle glaucoma: correlation with paraglaucoma and early chronic open angle glaucoma: correlation

7 Caprioli J, Klingbeil U, Sears M, Pope B. Reproducibility of optic disc measurement with computerised analysis of stereo video images. Arch measurement with computerised

8 Nasemann JE, Burk ROW, eds. Scanning laser ophthalmoscopy. Munich: Quintessenz, 1990.

9 Montgomery DMI. Measurement of optic disc and neuroretinal rim areas in normal and glaucomatous eyes. A new clinical method. Ophthalmology 1991 98: 50-9.

10 Lachenmayr BJ, Drance SM, Douglas GR, Mikelberg FS. Light-sense, flicker and resolution perimetry in glaucoma: a comparative study. Graefes Arch Clin Exp Ophthalmol 1991; 29: 246-51.

11 Quigley HA, Addicks EM, Green WR. Optic nerve damage in human glaucoma, III: quantitive correlation of nerve fibres and visual field defect in glaucoma, III: quantitive correlation of nerve fibres and visual field defect in glaucoma, ischaemic neuropat

12 Werner EB, Bishop KI, Koelle J, Douglas GR, Le Blanc RP, Mills RP, et al. A comparison of experienced clinical observers and statistical tests in detection of progressive visual field loss in glaucoma using automated perimetry. Arch Ophthalmol 1988; 106: 619-23.

\title{
Conjunctival melanoma
}

Conjunctival melanoma $(\mathrm{CM})$ is a rare unilateral disease of the middle aged and elderly. It is those centres where these cases are collected which have developed and reported current management strategies. ${ }^{1-6}$ For example, in this issue of the journal Paridaens et al report on 95 cases from 1948 to 1991 where orbital exenteration was undertaken for CM, and conclude that this drastic operation often fails to cure. As a professional community however, we have yet to pool the resources at our disposal to understand the nature of the condition. Until we do it will be difficult to assess whether there has been any change in the behaviour of CM.

While some ophthalmologists will never see a new case in their careers, most of us are confronted from time to time by lesions which might be CM. At this early point we should seek to avoid the pitfalls of generating needless anxiety while ensuring appropriate intervention and referral when necessary. This has become easier since the concept of primary acquired melanosis (PAM) has become widely accepted and has done much to clarify diagnostic and management strategy. ${ }^{378}$ Accordingly we have derived diagnostic algorithms for 'in-house' use which are published on page 592, which some readers may find useful.

Meanwhile the sevenfold increase in the prevalence of cutaneous melanoma is properly matched by the number of publications describing this cancer in Australia, Europe, and the USA in the past 20 years. $^{9-11}$ The incontrovertible epidemiological evidence for this increase has stimulated examination of possible aetiological factors ranging from a change in global irradiation, through social habits, to factors at the genetic and molecular level. It is worth asking if there are any parallels between pigmented tumours of the skin and the conjunctiva. Important questions, some prompted by recent publications, include:

(a) Is there a change in prevalence of PAM and/or CM in those countries where cutaneous melanoma is increasing?

(b) Do any of the risk factors applicable to cutaneous melanoma apply to $\mathrm{CM}$ - for example, pale skin, freckles, number of moles, sunburn? (c) Does the wearing of spectacles confer any protection against the development of CM and PAM?

(d) Are there genetic susceptibilities to tumours of the skin and eye, other than those which appear to exist for xeroderma pigmentosa $a^{12}$ and dysplastic naevus syndrome? ${ }^{13}$

(e) Is $\mathrm{CM}$ amenable to classification with regard to prognosis according to proliferative indices, chromosomal anomalies, oestrogen sensitivity (14-17 $^{17}$

Attempts to answer these and other questions will be greatly facilitated by comprehensive reporting of PAM and CM. Cancer registries exist for other conditions - for example, leukaemia, and attract good returns of data from enthusiasts. OPCS statistics currently do have an entry for ocular tumours. However, the entry is not subdivided into the different tumours of the eye, there is no entry for tumour related deaths, and there is likely to be considerable underreporting.

Should the reporting of all ocular tumours, including CM, be made automatic by ocular pathologists, or should we support and join the development of a clinical oncology information network ${ }^{18}$ Both could be developed through the offices of the Royal College of Ophthalmologists. Any such step would be complementary and contributory to the Ocular Oncology Group of the European Organisation for Research and Treatment of Cancer. (B Damato, 1994 personal communication) It should not be beyond us to develop the infrastructure for collating comprehensive data on ocular tumours. Jakobiec wrote of CM in 1980 as 'unfinished business', ${ }^{19}$ and years later this is still an apt description of this frightening lesion, whose only concession so far is its rarity.

A B TULLO R BONSHEK

Manchester Royal Eye Hospital,

Oxford Road,

Manchester M13 9WH

1 De Potter $\mathrm{P}$, Shields $\mathrm{CL}$, Shields JA, Menduke $\mathrm{H}$. Clinical predictive factors for development of recurrence and metastasis in conjunctival melanoma: review of 68 cases. Br 7 Ophthalmol 1993; 77: 624-30. 
2 Seregard S, Kock E. Conjunctival malignant melanoma in Sweden 1969-91. Acta Ophthalmol (Copenh) 1992; 70: 289-96.

3 Jakobiec FA, Folberg R, Iwamoto T. Clinicopathologic characteristics of premalignant and malignant melanocytic lesions of the conjunctiva. Ophthalmology 1989; 96: 147-66.

4 Lommatzsch PK, Lommatzsch RE, Kirsch I, Fuhrmann P. Therapeutic outcome of patients suffering from malignant melanomas of the conjunctiva. Br f Ophthalmol 1990; 74: 615-9.

5 Fuchs U, Kivela T, Liesto K, Tarkkanen A. Prognosis of conjunctival melanomas in relation to histopathological features. $\mathrm{Br} \mathcal{F}$ Cancer 1989; 59: melanomas in relation to histopathological features. Br ff Cancer 1989, 59

6 Jakobiec FA, Rini FJ, Fraunfelder FT, Brownstein S. Cryotherapy for conjunctival primary acquired melanosis and malignant melanoma. Ophthal

mology 1988; 95: 1058-70.
7 Folberg R, McLean IW, Zimmerman LE. Primary acquired melanosis of the conjunctiva. Hum Pathol 1985; 16: 129-35.

8 Folberg R, McLean IW. Primary acquired melanosis and melanoma of the conjunctiva: terminology, classification, and biologic behaviour. Hum Patho $1986 ; 17: 652-4$.

9 Koh HK. Cutaneous melanoma. N Engl F Med 1991; 325: 171-82.

$10 \emptyset$ sterlind A. Epidemiology on malignant melanoma in Europe. Rev Oncol 1992; 5: 903-8.
11 Burton RC, Coates MS, Hersey P, Roberts G, Chetty MP, Chen S, et al. An analysis of a melanoma epidemic. Int $\mathcal{F}$ Cancer 1993; 55: 765-70.

12 Paridaens AD, McCartney AC, Hungerford JL. Premalignant melanosis of the conjunctiva and the cornea in xeroderma pigmentosum. $\mathrm{Br} \mathcal{F}$ Ophthalmol 1992; 76: 120-2.

13 McCarthy JM, Rootman J, Horsman D, White VA. Conjunctival and uveal melanoma in the dysplastic nevus syndrome. Surv Ophthalmol 1993; 37: 377-86.

14 Seregard S. Cell proliferation as a prognostic indicator in conjunctival malignant melanoma. Am $\mathcal{F}$ Ophthalmol 1993; 116: 93-7.

15 Saornil MA, Marcus DM, Doepner D, Apolone G, Torre V, Albert DM. Nucleolar organizer regions in determining malignancy of pigmented conjucleolar organizer regions in determining malignancy

16 Paridaens AD, Seregard S, Minassian D, Hungerford JL, McCartney AC. AgNOR counts in conjunctival malignant melanoma lack prognostic value. BrF Ophthalmol 1992; 76: 621-3.

17 Paridaens DA, Alexander RA, Hungerford JL, McCartney AC. Oestrogen receptors in conjunctival malignant melanoma: immunocytochemical study using formalin fixed paraffin wax sections. $\mathcal{F}$ Clin Pathol 1991; 44: 840-3.

18 Karp SJ. Clinical oncology information network. $B M \mathcal{F} 1994 ; 308$ : 147-8.

19 Jakobiec FA. Conjunctival melanoma. Unfinished business. Arch Ophthalmol 1980; 98: 1378-84. 